OPEN ACCESS

Edited by:

John L. Provis,

University of Sheffield,

United Kingdom

Reviewed by:

Ionut Ovidiu Toma

Gheorghe Asachi Technical University

of laşi, Romania

Marija Nedeljkovic,

Delft University of

Technology, Netherlands

*Correspondence:

Jinrui Zhang

jinrui.zhang@tju.edu.cn

Specialty section:

This article was submitted to

Structural Materials,

a section of the journal

Frontiers in Materials

Received: 09 October 2018 Accepted: 14 August 2019

Published: 28 August 2019

Citation:

Song R, Zhao Q, Zhang J and Liu J

(2019) Microstructure and

Composition of Hardened Paste of

Soda Residue-Slag-Cement Binding Material System. Front. Mater. 6:211.

doi: 10.3389/fmats.2019.00211

\section{Microstructure and Composition of Hardened Paste of Soda Residue-Slag-Cement Binding Material System}

\author{
Rongjie Song ${ }^{1,2}$, Qingxin Zhao ${ }^{1,2}$, Jinrui Zhang ${ }^{3 *}$ and Jizhong Liu ${ }^{1,2}$ \\ ${ }^{1}$ State Key Laboratory of Metastable Materials Science and Technology, Yanshan University, Qinhuangdao, China, ${ }^{2}$ Key \\ Laboratory of Green Construction and Intelligent Maintenance for Civil Engineering of Hebei Province, Yanshan University, \\ Qinhuangdao, China, ${ }^{3}$ State Key Laboratory of Hydraulic Engineering Simulation and Safety, Tianjin University, Tianjin, China
}

In order to utilize industrial waste soda residue, a kind of binding material system based on soda residue-slag-cement has been developed. The microstructure and composition of hardened paste of the binding material system after curing for 28 days was analyzed by means of scanning electron microscope (SEM), energy dispersive X-ray spectroscopy (EDS), X-ray diffraction (XRD), and thermogravimetric-differential scanning calorimetry (DSC-TG). The main hydration products of binding material system after curing for 28 days were $\mathrm{C}-\mathrm{S}-\mathrm{H}$ gel and $3 \mathrm{CaO} \cdot \mathrm{Al}_{2} \mathrm{O}_{3} \cdot \mathrm{CaCl}_{2} \cdot 1 \mathrm{OH}_{2} \mathrm{O}$ crystal (Friedel's salt) with a needle bar and irregular shape. The $\mathrm{Ca} / \mathrm{Si}$ ratio of $\mathrm{C}-\mathrm{S}-\mathrm{H}$ gel in hydration products varied from 0.7 to 1.4 , the ratio of $\mathrm{n}(\mathrm{Cx}-\mathrm{S}-\mathrm{Hy}) / \mathrm{n}\left(3 \mathrm{CaO} \cdot \mathrm{Al}_{2} \mathrm{O}_{3} \cdot \mathrm{CaCl}_{2} \cdot 1 \mathrm{H}_{2} \mathrm{O}\right)$ varied in the range of 1.8-6.4. The C-S-H gel and Friedel's salts that densely arranged and closely bonded with pores and cracks constituted the main strength source of the whole soda residue-slag-cement binding material system.

Keywords: soda residue, slag, binding material, hydration products, Friedel's salt

\section{INTRODUCTION}

The rapid development of industry has driven the world economy. However, the resulting industrial waste occupied the land and polluted the soil, water and air, which caused pollution to the global environment (Chen, 2018). Researchers around the world have conducted many studies on the reuse of industrial wastes. There are various types of industrial by products, such as calcium carbide slag, blast furnace slag, fly ash, and so on. The technique of using calcium carbide slag as construction materials and alkaline activator has been successfully used by researchers (Bilondi et al., 2018; Hanjitsuwan et al., 2018; Siddiqua and Barreto, 2018). Zhang et al. (2017) used fly ash and high-magnesium nickel slag as solid materials to manufacture geopolymer cement under the room temperature conditions. The results showed that the compressive strengths of the geopolymer cements can achieve $60 \mathrm{MPa}$, which is comparable to hardened Portland cements and adequate for construction purposes. Wiemes et al. (2017) conducted an experiment with the incorporation of different types of industrial waste in brick manufacturing process. Three types of wastes were mixed with clay: automotive industry waste sludge, glass waste and wood ash. The results showed that brick production can be obtained with different types of industrial waste. Amin et al. (2017) researched chloride resistant cement from industrial waste through geopolymerization, the test showed that the highest compressive strength of cement was $18.85 \mathrm{MPa}$ and resistance to chloride 
attack was recorded for geopolymer with silica to alumina ratio of 2.7. Meanwhile, the resistance of geopolymer to magnesium chloride is greater than that of sodium chloride, and the attack of chloride cannot affect the geopolymer network when having optimum silica to alumina ratio. Self-compacting concrete was prepared by El Mir and Nehme (2017) utilizing industrial waste perlite powder, the results indicated that waste perlite powder had a significant pozzolanic effect on the concrete microstructure, resulting in a positive impact on the compressive strength of the concrete.

Soda residue was an industrial waste produced in the process of soda ash production by ammonia-soda process, whose chemical compositions are $\mathrm{CaCO}_{3}$ and soluble salt chloride. The storage and emission of soda residue had caused serious environmental problem (Yan, 2015; Gomes et al., 2016). The accumulation of soda residue will change the acidity and alkalinity of the soil in the region, cause soil salinization and affect the normal growth of vegetation. As time goes by, chloride ions in soda residue will gradually infiltrate into the ground, causing different degrees of pollution to underground water sources and seriously threatening the safety of surrounding residents' drinking water. The soda residue mountain formed by the accumulation of soda residue will occur landslides under the action of earthquake and other external forces, endangering the safety of people's lives and property. How to use soda residue has become the focus of attention in the engineering field. Therefore, a great deal of research work has been carried out by scholars. Uçal et al. (2018) investigated hydration characteristics of alinite cement, which was produced by using soda waste sludge as raw material. It was found that induction period of alinite cement was around 15-20 min and unlike Portland cement, hydration did not practically stop during this period. Up to $12 \%$ gypsum addition to alinite cement resulted in increased compressive strength. Zhao et al. (2019) had studied the crucial properties of fly ash-based geopolymers incorporating soda residue. The research showed that the compressive strength of the alkaliactivated fly ash-based samples incorporating about $20 \%$ soda residue curing for 60 and 180 days was 13.5 and $18.0 \mathrm{MPa}$, the geopolymers had low shrinkage and good thermal stability. Zhang et al. (2013) had prepared the concrete with some soda residue replacing the cement by mass. The mix proportion of the concrete was $45-49 \%$ of stone, $25-29 \%$ of sand, $10-14 \%$ of cement, $5-10 \%$ of soda residue, and $5-8 \%$ of water. The research showed that the concrete had good frost resistance and wear resistance. Liu et al. (2017) had researched the property of polymer after mixing soda residue and fly ash. The research showed that when the mass ratio of soda residue and fly ash was $<0.36$, the flexural strength and compressive strength of the fly ash- $\mathrm{NaOH}$ system increased with the proportion of soda residue, the addition of soda residue had a significant modification effect on the development of the system strength. Sun and Gu (2014) prepared a new soda residue curing agent by using soda residue, slag and fly ash as the main raw materials and a proper amount of desulphurization gypsum and compound activator were added to these main materials. The physical and mechanical property of the curing agent basically met the technical parameters of the P.C 32.5 composite cement. Liu et al. (2016) researched the baking-free brick that were prepared with soda residue as the main material. It was found that when soda residue, fly ash, steel slag, and stone powder were prepared according to the mass ratio of $4: 3: 2: 1$, the compressive strength of baking-free brick curing for 7 days was 14.0 MPa and was 20.6 MPa curing for 28 days. Sun et al. (2012) improved the expansive soil with soda residue as an additive. The research showed that the relative density, liquid limit, plastic index, free expansion rate, and load expansion of the expansive soil decreased noticeably with the increase of soda residue content, which indicated that the soda residue had obvious improvement effect on expansibility of expansive soil.

However, the consumption of soda residue still cannot meet the needs of society and environment. In order to expand the application scope and further reduce the pressure on the environment, a new kind of binding material system based on soda residue-slag-cement was developed through a series of experiments. The microstructure and composition were analyzed by the scanning electron microscope (SEM), energy dispersive X-ray spectroscopy (EDS), thermogravimetricdifferential scanning calorimetry (DSC-TG), and X-ray diffraction (XRD).

\section{EXPERIMENTAL}

\section{Raw Materials}

The soda residue used in the experiment came from San You group in Tangshan, Hebei, which was dried and crushed into fine powder particles with the maximum diameter of $0.16 \mathrm{~mm}$. The $\mathrm{XRD}$ pattern was shown in Figure 1. It was apparent that the peak of $\mathrm{CaCO}_{3}, \mathrm{CaSO}_{4}, \mathrm{CaCl}_{2}$, and $\mathrm{NaCl}$ appeared in Figure 1, which indicated that $\mathrm{CaCO}_{3}, \mathrm{CaSO}_{4}, \mathrm{CaCl}_{2}$, and $\mathrm{NaCl}$ were contained in the identified phases in the XRD diffractogram of soda residue. The slag in the experiment was S95 grade granulated blast furnace slag powder. The cement used in the soda residue-slagcement binding material system was Portland cement (P.II 42.5), cement used in preparing cement mortar specimen for strength comparison was ordinary Portland cement (P·O 42.5R). Both slag and cement came from Qinhuangdao municipal construction group co., LTD in Hebei. The chemical components of soda residue, slag and cement were shown in Tables 1, 2 respectively. The particle size of nature quartz river sand ranged from 0.16 to $2.36 \mathrm{~mm}$.

\section{Preparation of Mortar Specimens}

In the mortar specimen mix design, the water-binder ratio was fixed at 0.5, the sand-binder ratio was fixed as 3:1 and the mix proportions of the binding materials were shown in Table 3 . The cement mortar was stirred evenly and the specimens of $40 \mathrm{~mm}$ $\times 40 \mathrm{~mm} \times 160 \mathrm{~mm}$ were prepared. All mortar specimens were cured in the standard curing box of a controlled environment of $(20 \pm 2)^{\circ} \mathrm{C}$ and relative humidity $\geq 95 \%$ for 28 days and then used to test the flexural strength and compressive strength. Each group was molded into six mortar specimens, which were then taken for average calculation.

\section{Methods}

\section{SEM and EDS Test of Paste Specimens}

According to the test method described in the literature (Aughenbaugh et al., 2016), the paste specimens of $20 \mathrm{~mm} \times$ 
$20 \mathrm{~mm} \times 80 \mathrm{~mm}$ were prepared according to the mix proportion in Table 3, and then removed into containers of a controlled environment of $(20 \pm 2)^{\circ} \mathrm{C}$ and relative humidity $\geq 95 \%$ to be cured to the ages of 28 days. The microstructure of the hardened pastes curing for 28 days was observed by a Hitachi-3400N SEM after the vacuum and gold spray treatment, and the content of the elements of $\mathrm{Ca}, \mathrm{Si}$, and $\mathrm{Cl}$ in hydration products was analyzed by the energy dispersive EDS, then the ratio of $\mathrm{Ca} / \mathrm{Si}$ in the $\mathrm{C}-\mathrm{S}-\mathrm{H}$ gel and the ratio of $\mathrm{Si} / \mathrm{Cl}$ in the hydration products were calculated.

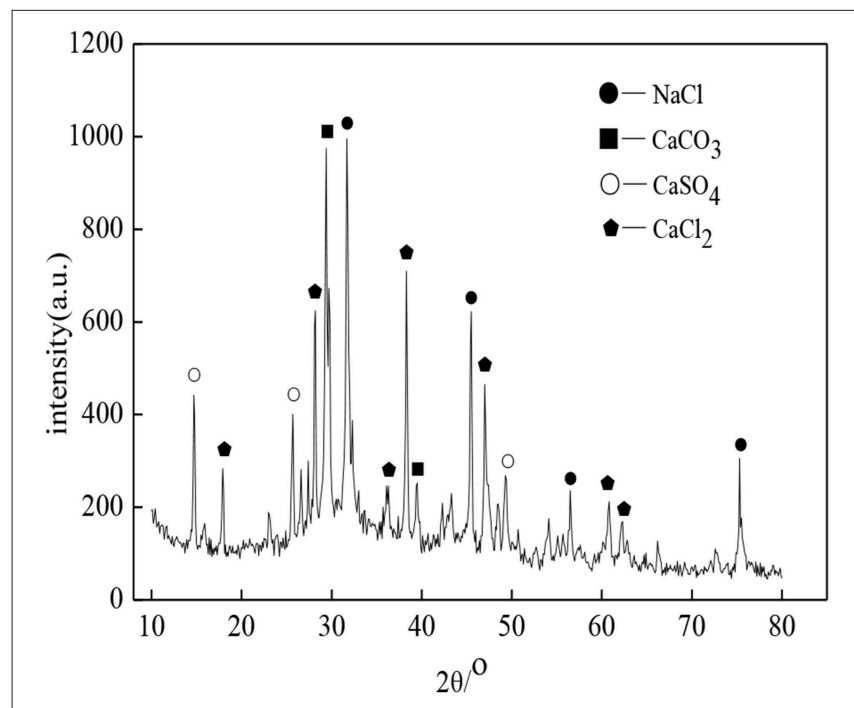

FIGURE 1 | XRD diffractogram of soda residue.

\section{Mineralogical Composition}

The component of hydration product was determined by XRD. The paste specimens were taken from the non-carbonated zone. During the testing period, the specimens were processed as following steps. Firstly, the non-carbonated specimens were split into small pieces and put in ethanol and were ground into fine powder particles till they all passed the sieve with the diameter of $0.12 \mathrm{~mm}$. Secondly, the powder was filtered in a vacuum by the suction filter bottle and diluted five times with ethanol and twice with ether. Then, the powder particles were dried in a vacuum drying oven with desiccant at $105^{\circ} \mathrm{C}$ for $24 \mathrm{~h}$. Finally, the powder particles were placed in the small glass bottles to be used for XRD. The $2 \theta$ values ranged from $10^{\circ}$ to $80^{\circ}$ and the scanning rate applied was $1^{\circ} / \mathrm{min}$ for all specimens.

\section{DSC-TG Test of Hydration Product Component}

Thermogravimetry-differential scanning calorimetries (DSCTG) of the paste specimens curing for 28 days were carried out by the STA 449F5 integrated thermal analyzer (Zhao et al., 2016). Firstly, the soda residue, slag and cement were dried in an oven at $105^{\circ} \mathrm{C}$ for $12 \mathrm{~h}$, and the coarse particles over $0.9 \mathrm{~mm}$ were removed by a standard sieve. Secondly, the flesh pastes were prepared based on mix proportions in Table 3, and the waterbinder ratio was 0.5 for all the pastes. Then the flesh pastes were sealed in plastic bags and then cured under the environment of $20 \pm 2{ }^{\circ} \mathrm{C}$ and relative humidity $\geq 95 \%$.

At the age of 28 days, the soda residue-slag-cement paste specimens were processed as per the following steps. Firstly, the specimens were split into small pieces and put in ethanol, and were then crushed into fine powder particles until all passed the sieve with the diameter of $0.12 \mathrm{~mm}$. Secondly, the powder

TABLE 1 | Chemical composition of soda residue w/\%.

\begin{tabular}{lllllllll}
\hline $\mathrm{Cl}^{-}$ & $\mathrm{CaO}$ & $\mathrm{Na}_{\mathbf{2}} \mathbf{O}$ & $\mathbf{S i O}_{\mathbf{2}}$ & $\mathbf{M g O}$ & $\mathbf{S O}_{\mathbf{3}}$ & $\mathbf{A l}_{\mathbf{2}} \mathbf{O}_{\mathbf{3}}$ & $\mathbf{K}_{\mathbf{2}} \mathbf{O}$ & $\mathrm{Fe}_{\mathbf{2}} \mathbf{O}_{\mathbf{3}}$ \\
\hline 39.11 & 35.12 & 13.04 & 4.17 & 2.97 & 2.80 & 2.06 & 0.33 & 0.29 \\
\hline
\end{tabular}

TABLE 2 | Chemical compositions of cement and slag w/\%.

\begin{tabular}{|c|c|c|c|c|c|c|c|c|c|c|c|}
\hline \multirow[t]{2}{*}{ Materials } & \multicolumn{11}{|c|}{ Chemical compositions (by mass)/\% } \\
\hline & $\mathrm{CaO}$ & $\mathrm{SiO}_{2}$ & $\mathrm{Al}_{2} \mathrm{O}_{3}$ & $\mathrm{Fe}_{2} \mathrm{O}_{3}$ & $\mathrm{MgO}$ & $\mathrm{TiO}_{2}$ & $\mathrm{~K}_{2} \mathrm{O}$ & $\mathrm{SO}_{3}$ & MnO & $\mathrm{Na}_{2} \mathrm{O}$ & $\mathrm{P}_{2} \mathrm{O}_{5}$ \\
\hline PC & 63.70 & 20.30 & 4.81 & 3.24 & 3.26 & 0.33 & 1.25 & 2.64 & 0.12 & 0.03 & 0.12 \\
\hline OPC & 56.50 & 20.60 & 6.27 & 2.79 & 3.15 & 0.26 & 2.34 & 3.28 & 0.16 & 0.05 & - \\
\hline Slag & 34.50 & 28.80 & 17.10 & 0.69 & 11.30 & 2.79 & 0.51 & 2.55 & 0.31 & 0.37 & - \\
\hline
\end{tabular}

TABLE 3 | The mix proportion of binders and the strength of mortar specimens.

\begin{tabular}{|c|c|c|c|c|c|c|c|}
\hline \multirow[t]{2}{*}{ Sample no. } & \multicolumn{3}{|c|}{ Mix proportion (by mass)/\% } & \multirow{2}{*}{$\begin{array}{c}7 \text { days } \\
\text { compressive } \\
\text { strength/MPa }\end{array}$} & \multirow{2}{*}{$\begin{array}{c}7 \text { days } \\
\text { flexural } \\
\text { strength/MPa }\end{array}$} & \multirow{2}{*}{$\begin{array}{c}28 \text { days } \\
\text { compressive } \\
\text { strength/MPa }\end{array}$} & \multirow{2}{*}{$\begin{array}{c}28 \text { days flexural } \\
\text { strength/MPa }\end{array}$} \\
\hline & Cement & Slag & Soda residue & & & & \\
\hline D1 & 20 & 70 & 10 & 13.5 & 2.1 & 44.6 & 6.7 \\
\hline D2 & 20 & 60 & 20 & 15.3 & 2.5 & 45.1 & 7.4 \\
\hline D3 & 20 & 50 & 30 & 12.6 & 1.8 & 39.6 & 5.9 \\
\hline
\end{tabular}


was filtered in a vacuum by the suction filter bottle and diluted five times with ethanol and twice with ether. Then the powder samples were dried in a vacuum drying oven with desiccant at $105^{\circ} \mathrm{C}$ for $24 \mathrm{~h}$. Finally, DSC-TG of the paste specimens curing for 28 days was carried out by the STA 449F5 integrated thermal analyzer. To prevent the carbonization of the specimens during the heating process, the Ar was used as the protective gas and the temperature rising rate was $10^{\circ} \mathrm{C} / \mathrm{min}$.

\section{RESULTS AND DISCUSSION}

\section{Mechanical Properties of Mortar Specimens}

Table 3 shows the flexural strength and compressive strength of mortar specimens after curing for 7 days and 28 days, with different percentages of binding materials. It can be seen from Table 3 that the mechanical property of D2 group curing for 28 days was optimum when the soda residue, slag and cement were prepared as the mass percentage of 2:6:2. Figure 2 shows the compressive strength of specimens at the age of 7, 28, 60, 90, and 120 days under the ratio of D2 group and the compressive strength of P.O 42.5R cement mortar specimen at the same age. It can be seen from Figure 2 that the compressive strength of mortar specimen of D2 group curing after 28 days was quite close to the strength of mortar specimens of P.O 42.5R cement.

It was apparent that compressive strength of $\mathrm{D} 2$ group curing for 7 days was $15.3 \mathrm{MPa}$, and the value was much lower than that of P.O 42.5R cement mortar specimens at age of 7 days. Slag is a potentially active cementitious material. The alkaline environment of soda residue makes the slag hydrate slowly. At the beginning, less hydration products are generated, and the system is less dense. With increasing age, the number of hydration products increases and the density increases gradually, and the compressive strength at 28 days increases significantly, reaching $45.1 \mathrm{MPa}$.

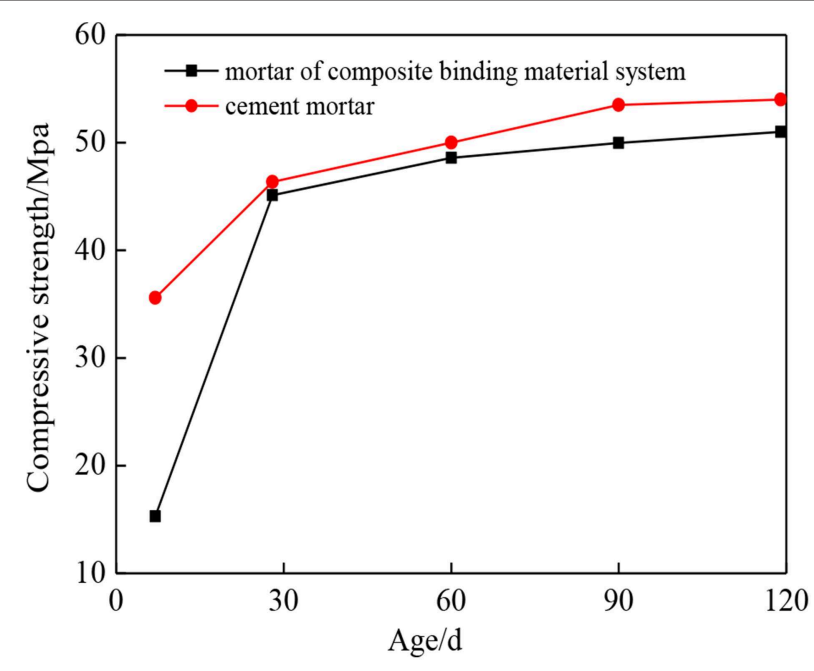

FIGURE 2 | Compressive strength comparison between the soda residue-slag-cement binding system and ordinary Portland cement mortar.

\section{Micro-Morphology Analysis of Hydration Products}

Figure 3 shows the SEM photographs of paste specimens of D2 group curing for 28 days. Figures $3 A-D$ indicated that the hydration products of D2 group cured to the ages of 28 days were rich, and the microstructure of hardened paste was formed basically. The hydration products were closely bonded with pores and cracks. The crystals were rod-shaped and irregularly shaped, and were distributed on the surface of hydration products. At the same time, a small amount of unreacted binding materials particles were distributed around the hydration products.

\section{Energy Dispersive Spectrum Analysis of Hydration Products}

Slices of paste of D2 group curing for 28 days were impregnated and polished to prepare BSE samples as shown in Figure 3E. In the SEM-BSE photographs, the detection dots were marked, respectively, in the position of different brightness in the image, and EDS analysis was carried out on every detection dot, respectively. The marked position was shown in Figure 3F and the detection results were shown in Figure 4 and Table 4.

It can be seen from Table 4 that the content of $\mathrm{Cl}$ elements at each detection position was far higher than the content of the $\mathrm{S}$ elements in the hydration products of D2 group. Therefore, it was inferred that there was a compound containing $\mathrm{Cl}$ elements in the hydration products. Meanwhile, it can be seen that the content of Si elements in the detection range was relatively large, because the diameter of the spectrum analysis range was larger than the size of the compound containing $\mathrm{Cl}$ elements, thus causing the existence of C-S-H gel in the various measuring regions. In the analysis of elements, it was assumed that all $\mathrm{Si}$ elements came from C-S-H gel and the hydration product containing $\mathrm{Cl}$ elements was $3 \mathrm{CaO} \cdot \mathrm{Al}_{2} \mathrm{O}_{3} \cdot \mathrm{CaCl}_{2} \cdot 10 \mathrm{H}_{2} \mathrm{O}$ crystal (Shao et al., 2013). Then the numbers of atoms of the $\mathrm{Ca}$ and $\mathrm{Cl}$ elements were subtracted from the numbers of atoms of the element in the measured region according to the elemental composition of $3 \mathrm{CaO} \cdot \mathrm{Al}_{2} \mathrm{O}_{3} \cdot \mathrm{CaCl}_{2} \cdot 10 \mathrm{H}_{2} \mathrm{O}$, subsequently, the numbers of atoms of $\mathrm{Ca}$ and $\mathrm{Si}$ elements in $\mathrm{C}-\mathrm{S}-\mathrm{H}$ gel were calculated. The result of the atomic weight of $\mathrm{Ca}$ and Si elements in C-S-H gel were shown in Table 5. It can be seen from Table 5 that the ratio of $\mathrm{Ca} / \mathrm{Si}$ in $\mathrm{C}-\mathrm{S}-\mathrm{H}$ gel on the spot 1 was 0.7 , the ratio of $\mathrm{Ca} / \mathrm{Si}$ in $\mathrm{C}-\mathrm{S}-\mathrm{H}$ gel on the spot 2 was 1.2 , the ratio of $\mathrm{Ca} / \mathrm{Si}$ in $\mathrm{C}-\mathrm{S}-\mathrm{H}$ gel on the spot 3 was 1.1 , and the ratio of $\mathrm{Ca} / \mathrm{Si}$ in $\mathrm{C}-\mathrm{S}-\mathrm{H}$ gel on the spot 4 was 1.4 when the hydration product containing $\mathrm{Cl}$ element was $3 \mathrm{CaO} \cdot \mathrm{Al}_{2} \mathrm{O}_{3} \cdot \mathrm{CaCl}_{2} \cdot 10 \mathrm{H}_{2} \mathrm{O}$ crystal. The ratio of $\mathrm{Ca} / \mathrm{Si}$ of the remaining portion in detection region was within the range of $\mathrm{Ca} / \mathrm{Si}$ ratio of $\mathrm{C}-\mathrm{S}-\mathrm{H}$ gel, thus, it was proved that the hydration product containing $\mathrm{Cl}$ elements was $3 \mathrm{CaO} \cdot \mathrm{Al}_{2} \mathrm{O}_{3} \cdot \mathrm{CaCl}_{2} \cdot 10 \mathrm{H}_{2} \mathrm{O}$ crystal.

In order to characterize the relative content of C-S-H gel and $3 \mathrm{CaO} \cdot \mathrm{Al}_{2} \mathrm{O}_{3} \cdot \mathrm{CaCl}_{2} \cdot 10 \mathrm{H}_{2} \mathrm{O}$ crystal in the hydration product of $\mathrm{D} 2$ group, the ratio of $\mathrm{Si} / \mathrm{Cl}$ was introduced, the ratio of which was shown in Table 5. It could be seen from Table 5 that the ratio of $\mathrm{Si} / \mathrm{Cl}$ was 3.0 on the spot 1 , the ratio of $\mathrm{Si} / \mathrm{Cl}$ was 1.8 on the spot 2 , the ratio of $\mathrm{Si} / \mathrm{Cl}$ was 0.9 on the spot 3 , and the ratio of $\mathrm{Si} / \mathrm{Cl}$ was 3.2 on the spot 4 . It was assumed that all the Si elements were 


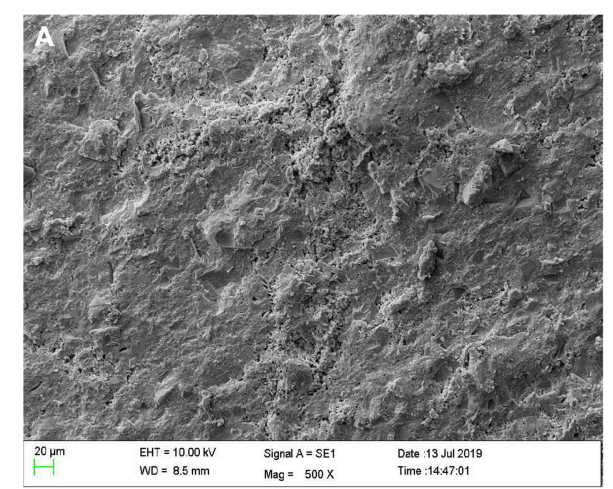

$500 \times$

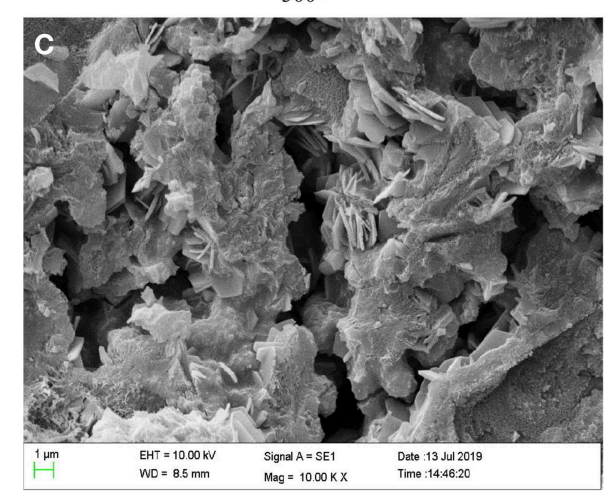

$10000 \times$

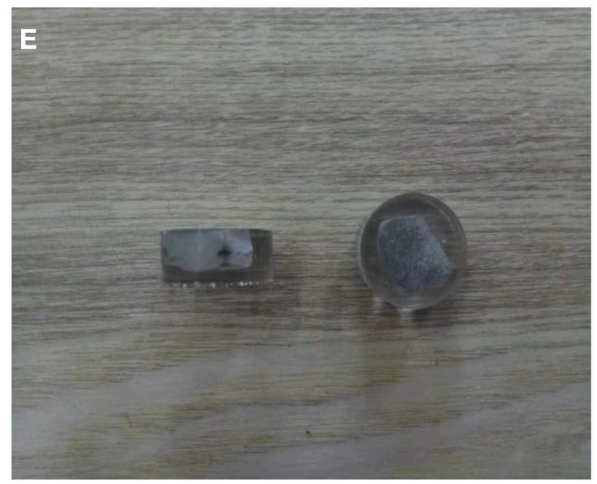

BSE specimens

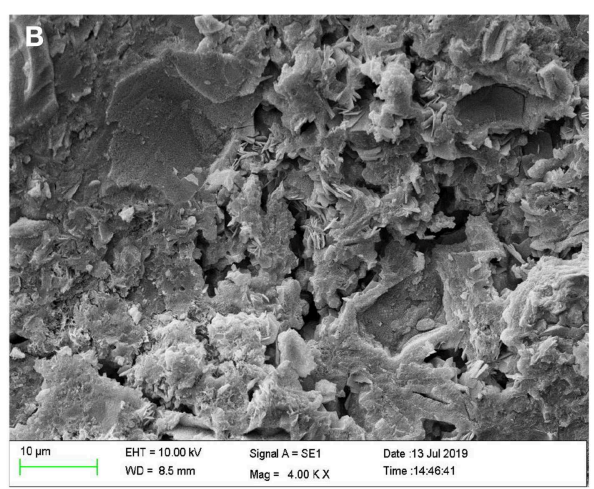

$4000 \times$

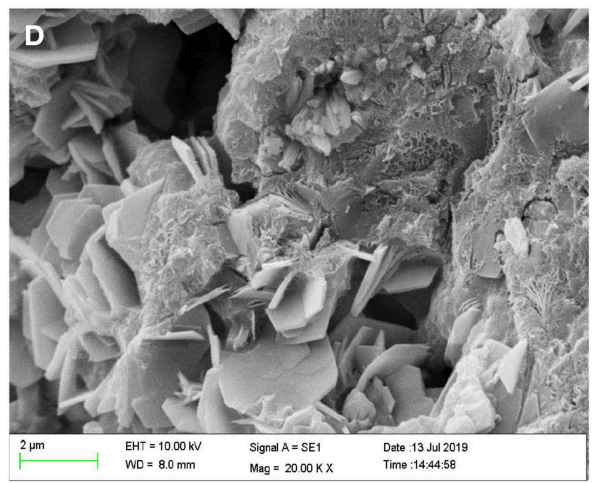

$20000 \times$

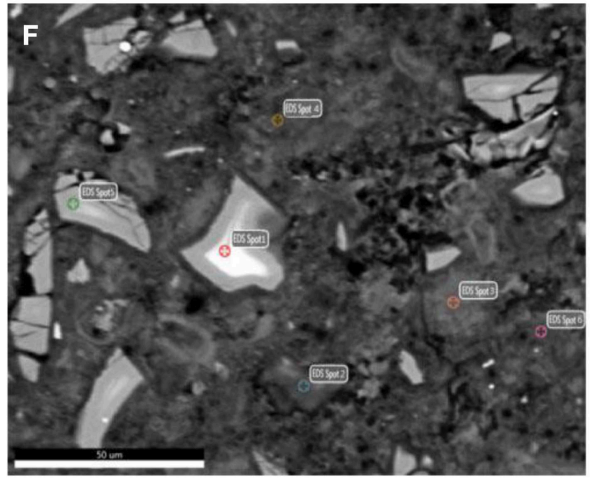

EDS detection dots $(2000 \times)$

FIGURE 3 | SEM images of the paste specimens of D2 group curing for 28 days and BSE specimens. (A) $500 \times$. (B) $4000 \times$. (C) $10000 \times$. (D) $20000 \times$. (E) BSE specimens. (F) EDS detection dots $(2000 \times)$.

derived from the C-S- $\mathrm{H}$ gel and all the $\mathrm{Cl}$ element were derived from the $3 \mathrm{CaO} \cdot \mathrm{Al}_{2} \mathrm{O}_{3} \cdot \mathrm{CaCl}_{2} \cdot 10 \mathrm{H}_{2} \mathrm{O}$ crystal. Meanwhile, the content of $\mathrm{Si}$ element in the C-S-H gel was the benchmark, it was known that the ratio of $n(C-S-H) / n\left(C a O \cdot \mathrm{Al}_{2} \mathrm{O}_{3} \cdot \mathrm{CaCl}_{2} \cdot 10 \mathrm{H}_{2} \mathrm{O}\right)$ on spot 1, spot 2, spot 3, and spot 4 was 6.0, 3.6, 1.8, and 6.4, respectively. Each detection position was representative when the detection marker was made on the position of different brightness in the EDS spectrum analysis, so the data measured at four positions also represent the overall situation of the hydration products. According to the analysis above, the variation range of $\mathrm{n}\left(\mathrm{C}_{\mathrm{x}}-\mathrm{S}-\mathrm{H}_{\mathrm{y}}\right) / \mathrm{n}\left(3 \mathrm{CaO} \cdot \mathrm{Al}_{2} \mathrm{O}_{3} \cdot \mathrm{CaCl}_{2} \cdot 10 \mathrm{H}_{2} \mathrm{O}\right)$ was $1.8-6.4$ in the hydration products. That is, the ratio of molar content of $\mathrm{C}_{x}-\mathrm{S}-\mathrm{H}_{\mathrm{y}}$ gel to the molar content of $\mathrm{CaO} \cdot \mathrm{Al}_{2} \mathrm{O}_{3} \cdot \mathrm{CaCl}_{2} \cdot 10 \mathrm{H}_{2} \mathrm{O}$ crystal was fluctuated in the range of 1.8-6.4. Therefore, $\mathrm{C}-\mathrm{S}-\mathrm{H}$ gel and $\mathrm{CaO} \cdot \mathrm{Al}_{2} \mathrm{O}_{3} \cdot \mathrm{CaCl}_{2} \cdot 10 \mathrm{H}_{2} \mathrm{O}$ crystals that densely arranged and closely bonded with pores and cracks were the main contributors to the strength of the whole soda residue-slag-cement binding material system.

To verify the accuracy of the analysis above, the detection points were marked and the energy dispersive spectrum analysis was carried out on different position of brightness. The marked position was shown in Figure $3 \mathrm{~F}$ and the detection results were shown in Table 4 and Figures 4E,F. According to the analysis method above, it can be calculated that the ratio of $\mathrm{Ca} / \mathrm{Si}$ in C-S-H 

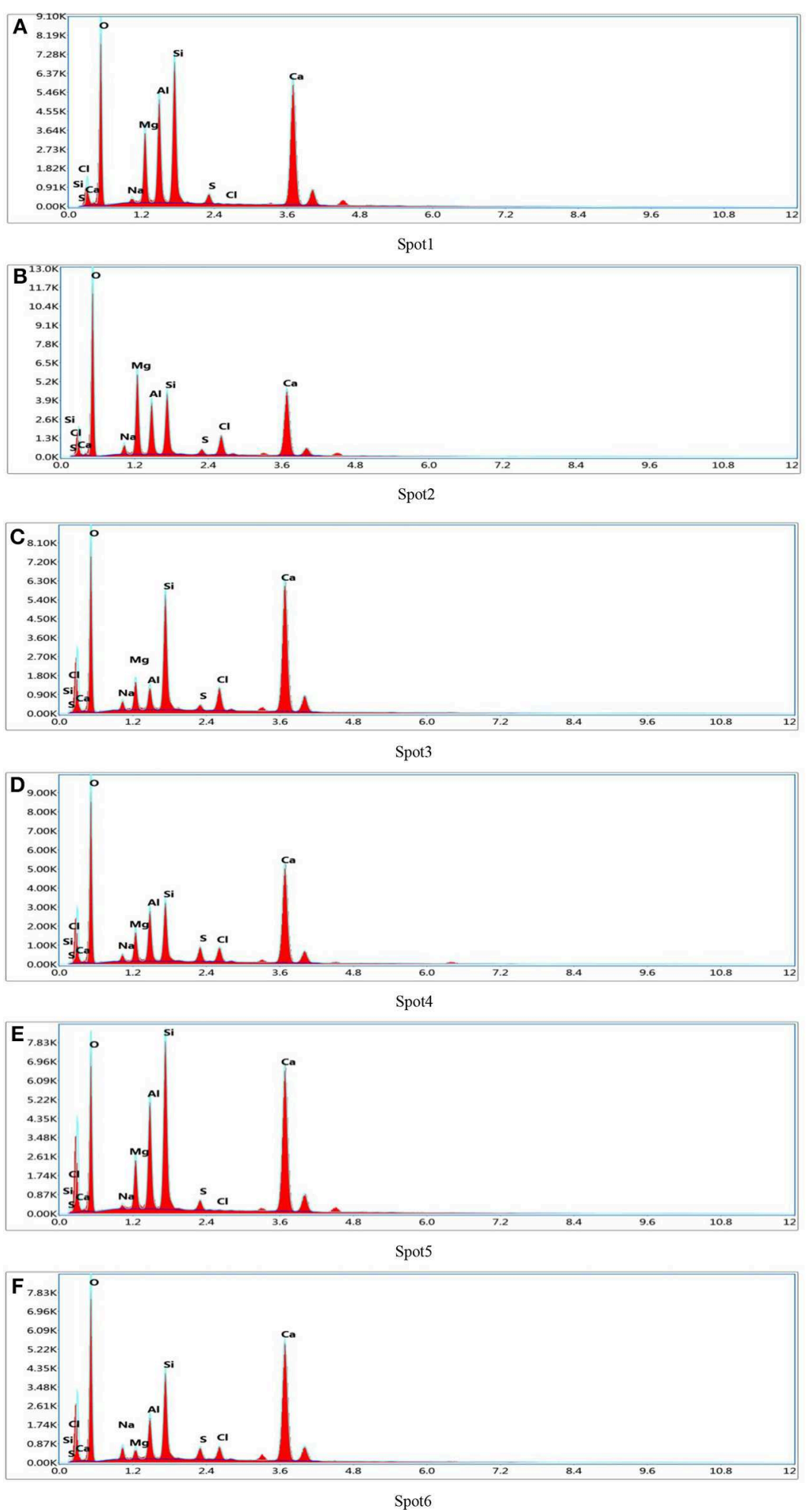

FIGURE 4 | EDS patterns of detection spot. (A) Spot 1. (B) Spot 2. (C) Spot 3. (D) Spot 4. (E) Spot 5. (F) Spot 6.

gel on the spot 5 was 0.75 and the ratio of $\mathrm{Ca} / \mathrm{Si}$ in $\mathrm{C}-\mathrm{S}-\mathrm{H}$ gel on the spot 6 was 1.3. The ratio of $\mathrm{Ca} / \mathrm{Si}$ of the remaining portion in detection region was within the range of $\mathrm{Ca} / \mathrm{Si}$ ratio of $\mathrm{C}-\mathrm{S}-\mathrm{H}$ gel, thus, it supported the conclusion above that the hydration product containing $\mathrm{Cl}$ elements was $3 \mathrm{CaO} \cdot \mathrm{Al}_{2} \mathrm{O}_{3} \cdot \mathrm{CaCl}_{2} \cdot 10 \mathrm{H}_{2} \mathrm{O}$ crystal. It could be seen from Table 5 that the ratio of $\mathrm{Si} / \mathrm{Cl}$ on 
spot 5 and spot 6 was 2.05 and 2.9, respectively. In other words, the ratio of $\mathrm{n}(\mathrm{C}-\mathrm{S}-\mathrm{H}) / \mathrm{n}\left(\mathrm{CaO} \cdot \mathrm{Al}_{2} \mathrm{O}_{3} \cdot \mathrm{CaCl}_{2} \cdot 10 \mathrm{H}_{2} \mathrm{O}\right)$ on spot 5 and spot 6 was 4.1 and 5.8, respectively. The ratio of $n(C-S-$ $\mathrm{H}) / \mathrm{n}\left(\mathrm{CaO} \cdot \mathrm{Al}_{2} \mathrm{O}_{3} \cdot \mathrm{CaCl}_{2} \cdot 10 \mathrm{H}_{2} \mathrm{O}\right)$ on the two measuring surfaces were within the range of 1.8-6.4, which support the conclusion that the ratio of molar content of $\mathrm{C}_{\mathrm{x}}-\mathrm{S}-\mathrm{H}_{\mathrm{y}}$ gel to the molar content of $\mathrm{CaO} \cdot \mathrm{Al}_{2} \mathrm{O}_{3} \cdot \mathrm{CaCl}_{2} \cdot 10 \mathrm{H}_{2} \mathrm{O}$ crystal was fluctuated in the range of 1.8-6.4.

TABLE 4 | Elementary compositions of detection spot.

\begin{tabular}{lcccccccc}
\hline \multirow{2}{*}{ Location } & \multicolumn{8}{c}{ Elementary compositions (by Atomic)/\% } \\
\cline { 2 - 9 } & $\mathbf{O}$ & $\mathbf{N a}$ & $\mathbf{A l}$ & $\mathbf{S i}$ & $\mathbf{S}$ & $\mathbf{C l}$ & $\mathbf{C a}$ & $\mathbf{M g}$ \\
\hline Spot 1 & 60.13 & 0.78 & 6.10 & 9.18 & 1.77 & 3.06 & 12.55 & 6.44 \\
Spot 2 & 61.31 & 1.93 & 5.46 & 5.71 & 0.53 & 3.17 & 13.19 & 8.69 \\
Spot 3 & 67.38 & 1.65 & 1.95 & 4.68 & 0.54 & 5.20 & 15.55 & 3.06 \\
Spot 4 & 67.02 & 1.32 & 4.72 & 6.62 & 1.35 & 2.07 & 13.41 & 3.49 \\
Spot 5 & 58.79 & 0.73 & 7.90 & 8.41 & 1.08 & 4.10 & 14.51 & 4.50 \\
Spot 6 & 69.39 & 2.41 & 3.62 & 6.72 & 1.01 & 2.32 & 13.38 & 1.21 \\
\hline
\end{tabular}

TABLE 5 | Calculation results of $\mathrm{Si}, \mathrm{Ca}$, and $\mathrm{Cl}$ (by atomic) for spot.

\begin{tabular}{|c|c|c|c|c|}
\hline & Item & $\mathrm{Si}$ & $\mathrm{Cl}$ & $\mathrm{Ca}$ \\
\hline \multirow[t]{5}{*}{ Spot 1} & Atomic of element for $\mathrm{Si}, \mathrm{Ca}$, and $\mathrm{Cl}$ & 9.18 & 3.06 & 12.55 \\
\hline & Atomic of $\mathrm{Ca}$ and $\mathrm{Cl}$ in $3 \mathrm{CaO} \cdot \mathrm{Al}_{2} \mathrm{O}_{3} \cdot \mathrm{CaCl}_{2} \cdot 10 \mathrm{H}_{2} \mathrm{O}$ & 0 & 3.06 & 6.12 \\
\hline & Atomic of remaining elements & 9.18 & 0 & 6.43 \\
\hline & $\mathrm{Ca} / \mathrm{Si}$ & & 0.7 & \\
\hline & $\mathrm{Si} / \mathrm{Cl}$ & & 3.0 & \\
\hline \multirow[t]{5}{*}{ Spot 2} & Atomic of element for $\mathrm{Si}, \mathrm{Ca}$, and $\mathrm{Cl}$ & 5.71 & 3.17 & 13.19 \\
\hline & Atomic of $\mathrm{Ca}$ and $\mathrm{Cl}$ in $3 \mathrm{CaO} \cdot \mathrm{Al}_{2} \mathrm{O}_{3} \cdot \mathrm{CaCl}_{2} \cdot 10 \mathrm{H}_{2} \mathrm{O}$ & 0 & 3.17 & 6.34 \\
\hline & Atomic of remaining elements & 5.71 & 0 & 6.85 \\
\hline & $\mathrm{Ca} / \mathrm{Si}$ & & 1.2 & \\
\hline & $\mathrm{Si} / \mathrm{Cl}$ & & 1.8 & \\
\hline \multirow[t]{5}{*}{ Spot 3} & Atomic of element for $\mathrm{Si}, \mathrm{Ca}$, and $\mathrm{Cl}$ & 4.68 & 5.20 & 15.55 \\
\hline & Atomic of $\mathrm{Ca}$ and $\mathrm{Cl}$ in $3 \mathrm{CaO} \cdot \mathrm{Al}_{2} \mathrm{O}_{3} \cdot \mathrm{CaCl}_{2} \cdot 10 \mathrm{H}_{2} \mathrm{O}$ & 0 & 5.20 & 10.40 \\
\hline & Atomic of remaining elements & 4.68 & 0 & 5.15 \\
\hline & $\mathrm{Ca} / \mathrm{Si}$ & & 1.1 & \\
\hline & $\mathrm{Si} / \mathrm{Cl}$ & & 0.9 & \\
\hline \multirow[t]{5}{*}{ Spot 4} & Atomic of element for $\mathrm{Si}, \mathrm{Ca}$, and $\mathrm{Cl}$ & 6.62 & 2.07 & 13.41 \\
\hline & Atomic of $\mathrm{Ca}$ and $\mathrm{Cl}$ in $3 \mathrm{CaO} \cdot \mathrm{Al}_{2} \mathrm{O}_{3} \cdot \mathrm{CaCl}_{2} \cdot 10 \mathrm{H}_{2} \mathrm{O}$ & 0 & 2.07 & 4.14 \\
\hline & Atomic of remaining elements & 6.62 & 0 & 9.27 \\
\hline & $\mathrm{Ca} / \mathrm{Si}$ & & 1.4 & \\
\hline & $\mathrm{Si} / \mathrm{Cl}$ & & 3.2 & \\
\hline \multirow[t]{5}{*}{ Spot 5} & Atomic of element for $\mathrm{Si}, \mathrm{Ca}$, and $\mathrm{Cl}$ & 8.41 & 4.10 & 14.51 \\
\hline & Atomic of $\mathrm{Ca}$ and $\mathrm{Cl}$ in $3 \mathrm{CaO} \cdot \mathrm{Al}_{2} \mathrm{O}_{3} \cdot \mathrm{CaCl}_{2} \cdot 10 \mathrm{H}_{2} \mathrm{O}$ & 0 & 4.10 & 8.20 \\
\hline & Atomic of remaining elements & 8.41 & 0 & 6.31 \\
\hline & $\mathrm{Ca} / \mathrm{Si}$ & & 0.75 & \\
\hline & $\mathrm{Si} / \mathrm{Cl}$ & & 2.05 & \\
\hline \multirow[t]{5}{*}{ Spot 6} & Atomic of element for $\mathrm{Si}, \mathrm{Ca}$, and $\mathrm{Cl}$ & 6.72 & 2.32 & 13.38 \\
\hline & Atomic of $\mathrm{Ca}$ and $\mathrm{Cl}$ in $3 \mathrm{CaO} \cdot \mathrm{Al}_{2} \mathrm{O}_{3} \cdot \mathrm{CaCl}_{2} \cdot 10 \mathrm{H}_{2} \mathrm{O}$ & 0 & 2.32 & 4.64 \\
\hline & Atomic of remaining elements & 6.72 & 0 & 8.74 \\
\hline & $\mathrm{Ca} / \mathrm{Si}$ & & 1.3 & \\
\hline & $\mathrm{Si} / \mathrm{Cl}$ & & 2.9 & \\
\hline
\end{tabular}

\section{XRD Analysis of Hydration Products}

Figure 5 shows the XRD patterns of paste specimens of D2 group cured to the age of 28 days. It was apparent that the peak of paste specimens $\left(3 \mathrm{CaO} \cdot \mathrm{Al}_{2} \mathrm{O}_{3} \cdot \mathrm{CaCl}_{2} \cdot 10 \mathrm{H}_{2} \mathrm{O}\right)$ appeared in Figure 5. As shown in the reference (Baquerizo et al., 2015), $3 \mathrm{CaO} \cdot \mathrm{Al}_{2} \mathrm{O}_{3} \cdot \mathrm{CaCl}_{2} \cdot 10 \mathrm{H}_{2} \mathrm{O}$, also known as Friedel's salt, which belongs to a compound of the AFm family. A variety of compounds contained in the AFm family, in which $3 \mathrm{CaO} \cdot \mathrm{Al}_{2} \mathrm{O}_{3} \cdot \mathrm{CaSO}_{4} \cdot \mathrm{nH}_{2} \mathrm{O}, 3 \mathrm{CaO} \cdot \mathrm{A}_{2} \mathrm{O}_{3} \cdot \mathrm{CaCO}_{3} \cdot \mathrm{nH}_{2} \mathrm{O}$, and $3 \mathrm{CaO} \cdot \mathrm{Al}_{2} \mathrm{O}_{3} \cdot \mathrm{CaCl}_{2} \cdot \mathrm{nH}_{2} \mathrm{O}$ were the typical compounds. $\mathrm{A}$ variety of ions will replace each other to produce complex compounds when a large number of mineral admixtures existed. AFm crystal was a six square sheet crystal, but it tended to show tiny needle rod and irregular sheet shape when it grew incompletely. As shown in Figure 3C, the crystal in the shape of needle rod and irregular sheet distributed on the surface of hydration products was the $3 \mathrm{CaO} \cdot \mathrm{Al}_{2} \mathrm{O}_{3} \cdot \mathrm{CaCl}_{2} \cdot 10 \mathrm{H}_{2} \mathrm{O}$ crystal.

It was apparent that the peak of paste specimens $\left(\mathrm{CaCO}_{3}\right)$ appeared in Figure 5. The presence of $\mathrm{CaCO}_{3}$ may be caused by carbonation of the $\mathrm{Ca}(\mathrm{OH})_{2}$ during the sampling and specimens preparation. Although the C-S-H gel belongs to the amorphous state and the spectral line was mainly diffuse peak, but there was a prominent "convex hull" phenomenon at $25-35^{\circ}$ in the XRD patterns, indicating that there was the C-S-H gel in the hydration products of the soda residue-slag-cement binding material system curing for 28 days (Wu et al., 2014).

\section{DSC-TG Analysis of Hydration Products}

The DSC-TG patterns of paste specimens of D2 group were shown in Figure 6. It can be seen from Figure 6 that there were seven main heat absorption peaks and two main exothermic peaks. The endothermic peaks that located, respectively, at $106.9,186.4,299.3,334.2,467,609.9$, and $672.6^{\circ} \mathrm{C}$ were corresponding to the temperature of decomposition of the hydration products. According to the literature (Yang and Xue,

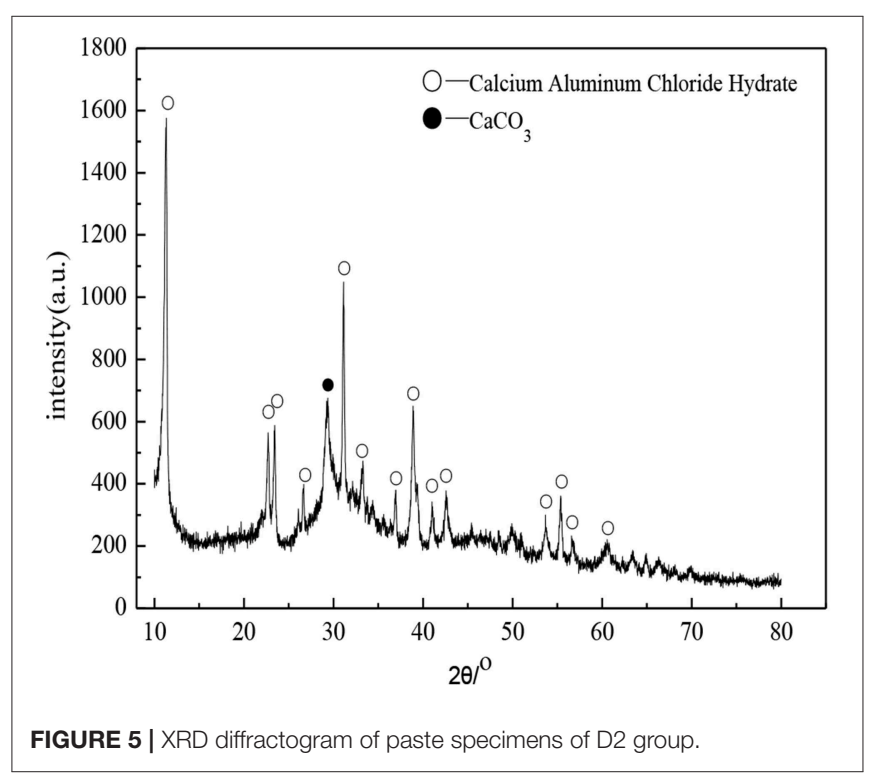




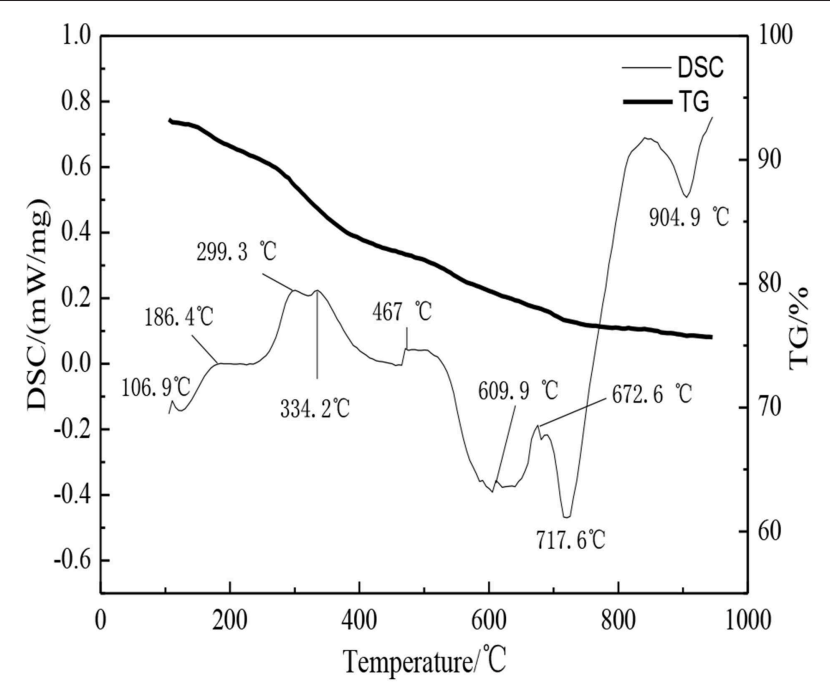

FIGURE 6 | DSC-TG patterns of paste specimens of D2 group.

2000), the endothermic peak at $106.9^{\circ} \mathrm{C}$ was due to the removal of water molecule in $3 \mathrm{CaO} \cdot \mathrm{Al}_{2} \mathrm{O}_{3} \cdot \mathrm{CaCl}_{2} \cdot 10 \mathrm{H}_{2} \mathrm{O}$, and forming $3 \mathrm{CaO} \cdot \mathrm{Al}_{2} \mathrm{O}_{3} \cdot \mathrm{CaCl}_{2} \cdot 6 \mathrm{H}_{2} \mathrm{O}$. The endothermic peak at $299.3^{\circ} \mathrm{C}$ resulted from $3 \mathrm{CaO} \cdot \mathrm{Al}_{2} \mathrm{O}_{3} \cdot \mathrm{CaCl}_{2} \cdot 6 \mathrm{H}_{2} \mathrm{O}$ continued taking off 5 crystalline water. The endothermic peak at 186.4, 334.2, and $467^{\circ} \mathrm{C}$ were caused by dehydration and heat absorption of C-S$\mathrm{H}$ gel. The crest at $609.9^{\circ} \mathrm{C}$ was due to the continuous hydration and heat absorption of calcium aluminum chloride hydrate. The existence of $\mathrm{CaCO}_{3}$ in the paste specimens was showed in the XRD patterns. Most of the carbonate mineral decomposition temperature are in the range of $600-900^{\circ} \mathrm{C}$. It can be seen that there was an endothermic peak at $859.5^{\circ} \mathrm{C}$ which was due to the decomposition reaction of $\mathrm{CaCO}_{3}$ resulting in releasing $\mathrm{CO}_{2}$ and generating $\mathrm{CaO}$. The exothermic peaks were at the position of 717.6 and $904.9^{\circ} \mathrm{C}$. The exothermic peak at $717.6^{\circ} \mathrm{C}$ was due to the further crystallization of calcium aluminum chloride hydrate. The exothermic peak at $862.2^{\circ} \mathrm{C}$ was due to the crystal transformation of the corresponding C-S-H gel and the transformation into the $\beta$-wollastonite (Wang and Yan, 2008, 2011). By the analyzation of DSC-TG, the existence of C-S-H gel and $3 \mathrm{CaO} \cdot \mathrm{Al}_{2} \mathrm{O}_{3} \cdot \mathrm{CaCl}_{2} \cdot 10 \mathrm{H}_{2} \mathrm{O}$ crystal in hydration products was evidenced.

\section{REFERENCES}

Amin, N., Nawab, L., and Ghani, U. (2017). Synthesis and characterization of chloride resistant cement from industrial waste through geopolymerization. $J$. Clean. Prod. 156, 577-580. doi: 10.1016/j.jclepro.2017.04.079

Aughenbaugh, K. L., Stutzman, P., and Juenger, M. C. G. (2016). Identifying glass compositions in fly ash. J. Front. Mater. 3, 1-10. doi: 10.3389/fmats.2016.00001

Baquerizo, L. G., Matschei, T., Scrivener, K. L., Saeidpour, M., and Wadsö, L. (2015). Hydration states of AFm cement phases. J. Cement Concr. Res. 73, 143-157. doi: 10.1016/j.cemconres.2015.02.011

Bilondi, M. P., Toufigh, M. M., and Toufigh, V. (2018). Using calcium carbide residue as an alkaline activator for glass powder-clay geopolymer. J. Constr. Build. Mater. 183, 417-428. doi: 10.1016/j.conbuildmat.2018.06.190

\section{CONCLUSIONS}

The icrostructure and composition of hardened paste of the soda residue-slag-cement binding material system were analyzed in this study. Several conclusions could be drawn as follows.

1) As the water-binder ratio was 0.5 , sand-binder ratio was $3: 1$, and soda residue-slag-cement mass ratio was $2: 6: 2$, the compressive strength of the mortar specimen $(40 \mathrm{~mm} \times$ $40 \mathrm{~mm} \times 160 \mathrm{~mm}$ ) was $45.1 \mathrm{MPa}$ and the flexural strength was 7.4 MPa, which was quite closed to the strength of ordinary Portland cement mortar and can be used in the preparation of non-reinforced building products.

2) Through the microscopic analysis on the paste specimens cured to the ages of 28 days, it was found that the main hydration products were the $\mathrm{C}-\mathrm{S}-\mathrm{H}$ gel and $3 \mathrm{CaO} \cdot \mathrm{Al}_{2} \mathrm{O}_{3} \cdot \mathrm{CaCl}_{2} \cdot 10 \mathrm{H}_{2} \mathrm{O}$ crystal. The $\mathrm{Ca} / \mathrm{Si}$ ratio of C-S-H gel in hydration products varied in the range of 0.7-1.4, and the ratio of $n\left(\mathrm{C}_{\mathrm{x}}-\mathrm{S}-\mathrm{H}_{\mathrm{y}}\right) / \mathrm{n}\left(3 \mathrm{CaO} \cdot \mathrm{Al}_{2} \mathrm{O}_{3} \cdot \mathrm{CaCl}_{2} \cdot 10 \mathrm{H}_{2} \mathrm{O}\right)$ varied in the range of 1.8-6.4. The C-S-H gel and Friedel's salts that densely arranged and closely bonded with pores and cracks constituted the main strength source of the whole soda residue-slag-cement binding material system together.

\section{AUTHOR CONTRIBUTIONS}

RS: experimental design, investigation, methodology, and writing. QZ: funding acquisition, investigation, methodology, project administration, and writing. JZ: conceptualization, data analysis, supervision, validation, writing, and revising. JL: data analysis, methodology, and writing.

\section{FUNDING}

Financial support from the National Natural Science Foundation of China under the grants of 51578477 and 51708403, the Innovative Research Group Science Fund of the National Natural Science Foundation of China under the grant of 51621092, the Key R\&D Project of Hebei Province under the grant of 19211505D, and the China Postdoctoral Science Foundation under the grants of 2018T110200 and 2018M640236 was gratefully acknowledged.

Chen, Y. C. (2018). Evaluating greenhouse gas emissions and energy recovery from municipal and industrial solid waste using waste-to-energy technology. J. J. Clean. Prod. 192, 262-269. doi: 10.1016/j.jclepro.2018.04.260

El Mir, A., and Nehme, S. G. (2017). Utilization of industrial waste perlite powder in self-compacting concrete. J. Clean. Prod. 156, 507-517. doi: 10.1016/j.jclepro.2017.04.103

Gomes, H. I., Mayes, W. M., Rogerson, M., Stewart, D. I., and Burke, I. T. (2016). Alkaline residues and the environment: a review of impacts, management practices and opportunities. J. Clean. Prod. 112, 3571-3582. doi: 10.1016/j.jclepro.2015.09.111

Hanjitsuwan, S., Phoo-ngernkham, T., Li, L. Y., Damrongwiriyanupap, N., and Chindaprasirt, P. (2018). Strength development and durability of alkali-activated fly ash mortar with calcium carbide residue as additive. 
J. Constr. Build. Mater. 162, 714-723. doi: 10.1016/j.conbuildmat.201 7.12.034

Liu, C. Y., Zhao, X. H., Zhu, N., Liu, Y. F., and Pang, Y. Z. (2017). Mechanical properties of fly ash-based geopolymers and modification mechanism of soda residue. J. Bull. Chin. Ceramic Soc. 36, 679-685. doi: 10.16552/j.cnki.issn1001-1625.2017.02.046

Liu, D. C., Li, Y., Liu, Y. J., Ge, W. Q., Yan, J. H., and Li, S. H. (2016). Preparation of baking-free brick by soda residue. J. Chin. J. Environ. Eng. 10, 3249-3254. doi: 10.12030/j.cjee.201511183

Shao, Y., Zhou, M., Wang, W. X., and Hou, H. B. (2013). Identification of chromate binding mechanisms in Friedel's salt. J. Constr. Build. Mater. 48, 942-947. doi: 10.1016/j.conbuildmat.2013.07.098

Siddiqua, S., and Barreto, P. N. M. (2018). Chemical stabilization of rammed earth using calcium carbide residue and fly ash. J. Constr. Build. Mater. 169, 364-371. doi: 10.1016/j.conbuildmat.2018.02.209

Sun, J. Y., and Gu, X. (2014). Engineering properties of the new non-clinker incorporating soda residue solidified soil. J. Build. Mater. 17, 1031-1035. doi: 10.3969/j.issn.1007-9629.2014.06.016

Sun, S. L., Zheng, Q. H., Tang, J., Zhang, G. Y., Zhou, L. G., and Shang, W. T. (2012). Experimental research on expansive soil improved by soda residue. J. Rock Soil Mech. 33, 1068-1612. doi: 10.16285/j.rsm.2012.06.045

Uçal, G. O., Mahyar, M., and Tokyay, M. (2018). Hydration of alinite cement produced from soda waste sludge. J. Constr. Build. Mater. 164, 178-184. doi: 10.1016/j.conbuildmat.2017.12.196

Wang, Q., and Yan, P. Y. (2008). Early hydration characteristics and paste structure of complex binding material containing high-volume steel slag. J. Chin. Ceramic Soc. 36, 1406-1416. doi: 10.14062/j.issn.0454-5648.2008. 10.027

Wang, Q., and Yan, P. Y. (2011). The influence of steel slag on the hydration of cement during the hydration process of complex binder. J. Sci. China Technol. Sci. 54, 388-394. doi: 10.1007/s11431-010-4204-0

Wiemes, L., Pawlowsky, U., and Mymrin, V. (2017). Incorporation of industrial wastes as raw materials in brick's formulation. J. Clean. Prod. 142, 69-77. doi: 10.1016/j.jclepro.2016.06.174
Wu, H., Ni, W., Cui, X. W., and Wang, S. (2014). Preparation of concrete sleeper using hot steaming steel slag with low autogenous shrinkage. J. Trans. Mater. Heat Treat. 35, 7-12. doi: 10.13289/j.issn.1009-6264.2014.04.002

Yan, W. J. (2015). Research on Performance and Mechanism of Mortar and Concrete Using Soda Residue as Mineral Admixture. Guangzhou: South China University of Technology.

Yang, N. R., and Xue, W. H. (2000). The Handbook of Inorganic Matalloid Materials Atlas. Wuhan: Wuhan University of Technology Press.

Zhang, Y., Jiang, H. B., and Wang, Y. L. (2013). The Concrete and Its Preparation Method With Soda Residue as Admixture. P. Chinese Patent. Application Number 201310220650.2. 2013-06-05.

Zhang, Z. H., Zhu, Y. C., Yang, T., Li, L. F., Zhu, H. J., and Wang, H. (2017) Conversion of local industrial wastes into greener cement through geopolymer technology: A case study of high-magnesium nickel slag. J. Clean. Prod. 141, 463-471. doi: 10.1016/j.jclepro.2016.09.147

Zhao, Q. X., He, X. J., Zhang, J. R., and Jiang, J. Y. (2016). Long-age wet curing effect on performance of carbonation resistance of fly ash concrete. J. Constr. Build. Mater. 127, 577-587. doi: 10.1016/j.conbuildmat.2016.10.065

Zhao, X. H., Liu, C. Y., Wang, L., Zuo, L. M., Zhu, Q., and Ma, W. (2019). Physical and mechanical properties and micro characteristics of fly ash-based geopolymers incorporating soda residue. J. Cement Concr. Comp. 98, 125-136. doi: 10.1016/j.cemconcomp.2019.02.009

Conflict of Interest Statement: The authors declare that the research was conducted in the absence of any commercial or financial relationships that could be construed as a potential conflict of interest.

Copyright (c) 2019 Song, Zhao, Zhang and Liu. This is an open-access article distributed under the terms of the Creative Commons Attribution License (CC BY). The use, distribution or reproduction in other forums is permitted, provided the original author(s) and the copyright owner(s) are credited and that the original publication in this journal is cited, in accordance with accepted academic practice. No use, distribution or reproduction is permitted which does not comply with these terms. 